\title{
Human exposure to nitro musks and the evaluation of their potential toxicity: an overview
}

Kathryn M Taylor ${ }^{1 *}$, Marc Weisskopf ${ }^{1,2}$ and James Shine ${ }^{1}$

\begin{abstract}
Synthetic nitro musks are fragrant chemicals found in household and personal care products. The use of these products leads to direct exposures via dermal absorption, as well as inhalation of contaminated dust and volatilized fragrances. Evidence also suggests that humans are exposed to low doses of these chemicals through oral absorption of contaminated liquids and foods. As these compounds are lipophilic, they and their metabolites, have been found not only in blood, but also breast milk and adipose tissue. After personal use, these environmentally persistent pollutants then pass through sewage treatment plants through their effluent into the environment. Little is known about the biological effects in humans after such a prolonged low dose exposure to these chemicals. While epidemiologic studies evaluating the effects of nitro musk exposures are lacking, there is limited evidence that suggest blood levels of nitro musks are inversely related to luteal hormone levels. This is supported by animal models and laboratory studies that have shown that nitro musks are weakly estrogenic. Nitro musks exposure has been associated with an increased risk of tumor formation in mice. The evidence suggests that while nitro musks by themselves are not genotoxic, they may increase the genotoxicity of other chemicals. However, animal models for nitro musk exposure have proven to be problematic since certain outcomes are species specific. This may explain why evidence for developmental effects in animals is conflicting and inconclusive. Given that animal models and cell-line experiments are suggestive of adverse outcomes, further epidemiologic studies are warranted.
\end{abstract}

Keywords: Nitro musks, Fragrance, Persistent pollutant, Review

\section{Introduction}

Synthetic nitro musks are alkylated nitrobenzene derivatives. These chemicals are an anthropogenic component in fragrant compositions. They were synthesized in the early 1900 s as inexpensive substitutes for natural macrocyclic musks used in perfumes [1]. Nitro musks generally refer to the five most commercially relevant fragrant compounds (Figure 1): ketone musk (4-tert-butyl-2,6dimethyl-3,5-dinitroacetophenone), musk ambrette (2,6dinitro-3-methoxy-4-tert-butyltoluene), musk moskene (1,1,3,3,5-pentamethyl-4,6-dinitro-2H-indene), musk tibetene (1-tert-butyl-3,4,5-trimethyl-2,6-dinitrobenzene) and

\footnotetext{
* Correspondence: kmtaylor@hsph.harvard.edu

'Department of Environmental Health, Harvard School of Public Health, 677 Huntington Avenue, Boston, MA 02115, USA

Full list of author information is available at the end of the article
}

musk xylene (1-tert-butyl-,5-dimethyl-2,4,6-trinitrobenzene). Musk moskene and musk tibetene have been prohibited from use in fragrant products because of adverse outcomes from structurally similar compounds [2]. Musk ambrette has been discontinued from use because its consumption was associated with hind limb weakness in rats and observed neuropathologic changes in the brain, spinal cord and peripheral nerves [3]. Ketone musk and musk xylene continue to be used as additives in detergents, fabric softener, household cleaning products and other fragrant non-cosmetic products with musk xylene being the most widely used nitro musk [4].

In 2008, under the authority of the Registration, Evaluation, Authorization and Restriction of Chemicals (REACH) regulation, musk xylene was classified as a substance of high concern with a very persistent, very bioaccumulative (vPvB) designation. A restricted use warning was placed on musk

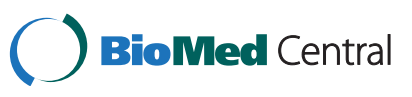


<smiles>COc1c(C(C)(C)C)cc([N+](=O)[O-])c(C)c1[N+](=O)[O-]</smiles>

Musk Ambrette<smiles>CC(=O)c1cc([N+](=O)[O-])c(C(C)(C)C)c([N+](=O)[O-])c1</smiles>

Musk Ketone<smiles>Cc1c([N+](=O)[O-])cc2c(c1[N+](=O)[O-])C(C)(C)CC2(C)C</smiles>

Musk Moskene<smiles>Cc1c(C)c([N+](=O)[O-])c(C(C)(C)C)c([N+](=O)[O-])c1C</smiles>

Musk Tibetene<smiles>Cc1c([N+](=O)[O-])c(C)c([N+](=O)[O-])c(C(C)(C)C)c1[N+](=O)[O-]</smiles>

Musk Xylene

Figure 1 Structural formulas of the five most commercially relevant synthetic nitro musks.

ketone. They found that nitro musk compounds do not degrade easily, causing them to be highly stable and ubiquitous in the environment [5].

Nitro musks have been largely replaced by polycyclic musks due to banning of these compounds in several countries [6,7]. However, nitro musks are still being produced in China and India and used in non-cosmetic compounds in the United States that have not been reformulated. Given the environmental persistence and the continued use of nitro musks even at a decreased level, there are concerns for the effects of long-term exposure. This overview is designed to evaluate the literature on nitro musks and discuss areas for further research.

\section{Background}

\section{Human exposures}

The primary source of exposure to synthetic musks is through exposure to scented personal care products or scented household goods. In a report evaluating the concentrations of synthetic musks in personal care products in China, Lu et al. found musk xylene in $19 \%$ of the products and they found musk ketone in $57 \%$ of the products tested. These products included hair care products, body washes, toilet soaps, skin lotions and make up. The highest concentration of musk xylene was found in skin lotions with a mean concentration of $0.16 \mathrm{ug} / \mathrm{g}$ of lotion. The highest concentration of musk ketone was found in hair care products with a mean concentration of $8.12 \mathrm{ug} / \mathrm{g}$ of product [8].
The three main routes of exposure to nitro musks are through inhalation, dermal absorption and ingestion. $\mathrm{Lu}$ et al. [9] tested dust from a random sampling of homes in China finding musk ketone in $98.7 \%$ of the homes at a median concentration of $13.7 \mathrm{ng} / \mathrm{g}$ and musk xylene at a median concentration of $11.8 \mathrm{ng} / \mathrm{g}$ in $86.4 \%$ of the homes. This raises concern for inhalation of nitro musks through residual dust in the home [9]. However, human exposure to nitro musks via inhalation from the environment has been found to be minimal suggesting that inhalation from direct use is probably a more important exposure [10].

Dermal exposure to fragrances was thought to be an important route of exposure to musk. However, evidence suggests that absorption of dermally applied nitro musks is low. In a study by Hawkins et al. [11] when musk ketone and musk xylene were separately applied dermally to the backs of seven participants, the study found that after 6 hours, they were able to recover $86 \%$ of applied musk ketone with only $0.49 \%$ found in the urine and less than $0.01 \%$ in the feces and they were able to recover a range of $90-94 \%$ of musk xylene with $0.2-0.3 \%$ excreted in the urine and none found in the feces. Neither chemical was found in the blood. Hutter et al. [12] reached similar findings when they evaluated the association between dermal absorption through cosmetic use and blood levels of synthetic musks. Lignell et al. [13] looked at the effect of dermal absorption of nitro musks through perfume application in lactating women. They found that perfume use 
during pregnancy was not predictive of levels of musk ketone and musk xylene in breast milk. However, Eisenhardt et al. [14] found that blood levels of nitro musk were associated with use of cosmetics, in particular with perfume use, which would suggest an association with dermal absorption but also could be due to inhalation. However, it appears they did not control for strong predictors of lipophilic chemical concentrations in the blood such as age, number of children breastfed or Body Mass Index when evaluating this relationship. This suggests that percutaneous absorption might not be as significant as initially thought, and so should be controlled for in exposure analyses but might not be as important of a route of exposure.

Considering that most nitro musks have been replaced by polycyclic musks in many products applied dermally, oral exposure through contaminated water or food might be a big contributor to nitro musk presence in the blood, breast milk, and lymphocytes [4]. This is supported by a study performed by Riedel and Dekant [15] in which both dermal and oral exposures to musk xylene were assessed in 12 volunteers over a 96 hour exposure. The percentage of dose administered found in plasma was an order of magnitude greater for oral exposure when compared with dermal exposure. Nitro musks have been found at concentrations ranging from below the limit of detection to $470 \mathrm{ng} / \mathrm{g}$ of lipid weight in freshwater fish samples, a result of sewage runoff into aquatic systems. Because of this consumption of contaminated fish may be an important exposure to consider [16]. However, while varying levels of nitro musks have been found in fish samples, Kafferlein and Angerer found that dietary intake of fish, assessed by a food frequency questionnaire, was not correlated with blood levels of nitro musks $[1,17,18]$.

Most human studies involving nitro musks have looked to assess the toxicokinetics of the chemicals once the nitro musks are absorbed. Upon absorption by the body, musk xylene can go through a reduction process that produces nitro derivatives. One of these derivatives, 1-tert-butyl-3,5-dimethyl-4-amino-2,6-dinitrobenzene has been shown to bind to hemoglobin and is a biotransformation product that is often found in urine [19]. The halflife of musk xylene ranges from 60-94 in the body [20]. This long half-life can be explained by a two compartment kinetic model where musk is either initially biotransformed by the body and excreted or distributed by the blood into a second compartment, in this case, the adipose tissue [15].

Nitro musks have a low range (4.3-4.9) of octanolwater partition coefficients indicating that they are lipophilic [21]. In 1994, studies began finding the presence of nitro musks in human adipose tissue and milk samples. Levels of nitro musks ranged from 0.01 to $0.22 \mathrm{mg} / \mathrm{kg}$ of fat in adipose samples and 0.01-0.19 mg/ $\mathrm{kg}$ of fat in milk samples [22]. In a study performed in Massachusetts on breast milk, Reiner et al. [23] found similar results with ranges of nitro musks found between $0.02-0.238 \mathrm{mg} / \mathrm{kg}$ of fat. Maternal age was not correlated with the levels of musks in breast milk, which is not consistent with most persistent organic pollutants. There was an inverse relationship between number of children breastfed previously and breast milk concentration, which is to be expected with lipophilic pollutants. However, this relationship was not significant.

\section{Musks in the environment}

Although human use of household and personal care products containing nitro musks is the primary route of human exposure, it was the presence of these compounds in environmental samples that originally drove concern about the biological and environmental effects of nitro musks in the 1980s. Yamagishi et al. [17] found their presence in more than $80 \%$ of freshwater fish samples, river water, and waste water taken from multiple sampling stations on the Tama River and Tokyo Bay. Since then nitro musks have been found in the biota and marine environments of the Baltic Sea, the North Sea, the Vlatava River in Prague, and Lake Michigan in the U.S. [1,24,25].

Nitro musks are not easily degradable, which accounts in part for their widespread presence in environmental samples. Nonetheless when nitro musks make their way from personal use settings and into wastewater, passage through sewage treatment plants does appear to degrade the nitro musks somewhat as by-products of nitro musks have been found in sampled sewage treatment plant effluents [6]. However, sewage treatment plants only degrade between $46-54 \%$ of the nitro musks that enter the plant prior to releasing their effluent back into the environment [7]. Therefore, even with such treatment, the potential for environmental exposure remains. Furthermore, the biotransformation products of nitro musks created by the sewage treatment process might also be of interest in risk assessment. Biotransformation products of nitro musks have been found in aquatic systems at higher concentrations than the parent compound indicating that transformed products of nitro musks are also environmentally persistent $[17,24,26]$.

Wastewater effluent has the ability to affect the concentrations of chemicals in surface water. This is of importance when contaminated water sources are used to supply water treatment plants or where they are used to recharge groundwater. Herberer et al. [27] found that some organic pollutants found in tap water were correlated with the levels of surface water filtration and intentional ground water replenishment in Berlin. In the United States, recycled wastewater is currently used for indirect potable reuse and non-potable reuse, meaning reused water is not directly used for tap water. However, 
a report put out by the National Committee on the Assessment of Water Reuse as an Approach to Meeting Future Water Supply Needs [28] declared that reused water could be used to augment surface water supplies which could be used for drinking water sources. This would create a closed water system loop or a semi-closed water system loop. This raises concern over how this will affect the concentrations of nitro musks and other environmentally stable pollutants in drinking water. Evidence suggests that areas that use closed or semi-closed looped water replenishment systems see a gradual increase of contaminant concentration over time. This effect is a result of low surface water flow and increased sewage effluent being added to surface waters [27,29].

An interesting secondary source of nitro musks to the environment, specifically musk ketone, may be melting glaciers. This was demonstrated in Lake Oberaar, a glacier fed lake where spikes of persistent organic pollutants were detected in glacier runoff [30]. This was even seen for contaminants whose use had long been discontinued. This suggests that even if nitro musk production was discontinued there is still a potential for exposure.

The persistent nature of musks in the environment has been well documented. Furthermore, a vast number of people may be exposed to these chemicals. Although a consensus has not been reached over the biological effects of the continuous, low-dose exposures humans may experience, it is important that possible health outcomes from such exposures to nitro musks are assessed.

\section{Toxicity}

Animal and laboratory studies of nitro musks have largely focused on three main areas: developmental effects due to perinatal and early childhood exposure, endocrine effects, and carcinogenic effects. A summary of the studies used in this overview can be found in Additional file 1.

Studies of developmental effects have focused on adverse birth outcomes across species, such as the ability to conceive and the viability of the embryos, and have found conflicting results. Exposure of pregnant rats to $45 \mathrm{mg} / \mathrm{kg} /$ day of musk ketone or $200 \mathrm{mg} / \mathrm{kg} /$ day of musk xylene, was not shown to have any adverse effect on the embryo [31]. In zebrafish, musk ketone between the levels of 0.1 and $10 \mathrm{mg} / \mathrm{g}$ of food/day was found to reduce the body weight of spawning females up to $38 \%$ and reduce the number of eggs/female/day up to $95 \%$ [32]. Embryos that were exposed to musk ketone at levels higher than $10 \mu \mathrm{g} / \mathrm{l}$ in the surrounding water had decreased early life stage survival [32]. When embryos of South African clawed frogs were exposed to $400 \mu \mathrm{g} / \mathrm{l} /$ day of either musk ketone, musk xylene or musk moskene in the surrounding water for 11 days, there was increasing larvae mortality for each increasing day of exposure [33].
Once the lipophilicity of nitro musks was recognized there was general concern over the possible endocrine modulating effects of these chemicals. This is because many similar aromatic, lipophilic compounds have been shown to have endocrine receptor binding capabilities $[34,35]$. One of the first studies, investigating potential endocrine effects, looked at the binding capability of musk xylene, musk ketone, musk moskene and their derivatives to the estrogen receptors in rainbow trout and the South African clawed frog. There was no observed binding of musk xylene, musk ketone or musk moskene to the estrogen receptors in both species. However, there was competitive binding of the estrogen receptors by three of the derivatives, 4- $\mathrm{NH}_{2}$-musk xylene, $2-\mathrm{NH}_{2}$ musk xylene, and $2-\mathrm{NH}_{2}$-musk ketone, in both species after exposure to the chemicals for 20 hours at concentrations of $10^{-6}$ to $10^{-3} \mathrm{M}$ in surrounding media, which is well above environmentally relevant levels. The binding affinity of these derivatives were up to 375 times lower than estradiol and up to 150 times lower than bisphenol A [36].

Bitsch et al. [37] conducted an E-screen assay to detect estrogenic activity using human MCF-7 breast cancer cells exposed to $10 \mathrm{mmol}$ of either musk xylene or musk ketone per liter of test substance or $5 \mathrm{mmol}$ of other nitro musk derivatives per liter of surrounding media. Estrogenic activity was confirmed by a significant increase in the proliferation of human breast cancer cells by $29 \%$ for musk xylene, by $97 \%$ for musk ketone and by $29 \%$ for p-amino-musk-xylene (a musk xylene derivative) when compared to the negative control. This increased proliferation was eradicated when the musks were added in the presence of 1 umol/L of tamoxifen, an anti-estrogenic drug, indicating that the musk effects were mediated, at least partly by the estrogen receptor. However, relative proliferation potency for the nitro musks in this assay was approximately 30,000 times lower than estradiol.

Increased concern for the potential carcinogenic effects of nitro musks was raised by a study of Maekawa et al. [38], which found that mice fed with food containing $0.075 \%$ or $0.15 \%$ musk xylene had up to three times as many tumors upon post-mortem inspection than control mice. Carcinogenicity studies after the Maekawa study focused on examining whether these chemicals were genotoxic. Multiple studies using various tests for genotoxicity in rats, E. coli PQ27 cells, human lymphocytes, and human hepatoma cell lines indicated that nitro musks were not genotoxic [39-41]. These results implied that there were other processes occurring in vivo to promote tumor genesis.

One potential pathway to explain this increase in tumor genesis after exposure to nitro musks is that it could be a result of nitro musks interaction with other toxins to increase the potency of known genotoxicants. 
Using the E. coli genotoxicity assay as an indicator of DNA damage, musk ketone, but not musk xylene, was shown to increase the toxicity of benzo-a-pyrene, 2 -aminoanthracene and aflotoxin B1 in rats when exposed to levels higher than $10 \mathrm{mg}$ of musk ketone per day [42]. This was confirmed using a micro nucleus test on musk ketone exposed human derived Hep G2 cells. When the Hep G2 cells were exposed to 5-5000 ng/l of musk ketone and $0.2 \mathrm{ug} / \mathrm{ml}$ of benzo-a-pyrene, no biological interaction occurred. However, when the cells where exposed to musk ketone 28 hours before the addition of benzo-a-pyrene, there was a synergistic effect showing an increase in the genotoxic effects of benzo-a-pyrene exposure [43]. The enhanced effect of benzo-a-pyrene after musk ketone exposure may be explained by the ability of musk ketone and musk xylene, injected individually, to induce production of CYP-4501A2, CYP-4501A3, and CYP-450IB2 which was initiated when rats were injected at doses starting at $10 \mathrm{mg}$ of each musk per $\mathrm{kg}$ of body weight. These enzymes are produced in response to exposure to xenobiotics in order to reduce or oxidize chemicals in the body. This response is usually beneficial but can sometimes have deleterious effects if the xenobiotic becomes more reactive after its transformation $[44,45]$. In contrast, Schnell et al. [46] found that both musk xylene and musk ketone inhibit the catalytic processes of CYP4501A in carp, suggesting that nitro musk interaction with CYP450 is likely species-specific $[44,45]$.

Another pathway for the promotion of tumor genesis was proposed by Luckenbach and Epel [47]. They found that musk xylene and musk ketone could inhibit the effectiveness of multidrug efflux transporters in marine mussels. A major consequence of this inhibition is loss of the cell's ability to remove xenobiotics, including known carcinogens, allowing them to remain in the cell longer. The effects of an exposure to 2 hours of synthetic musks took between 24 and 48 hours to be reversed.

\section{Health outcomes}

There has been one case control study that has evaluated possible health outcomes associated with nitro musk exposure. This study by Eisenhardt et al. [14] analyzed the association between musk ketone and musk xylene blood levels and endocrine and gynecological problems in premenopausal women at an endocrinological outpatient clinic. They found that women presenting with premenstrual syndrome had on average 24 ng musk ketone per liter of blood higher than women who did not present with premenstrual syndrome $(\mathrm{p}=0.014)$. They also found that musk xylene levels were inversely associated with levels of the luteal phase hormones, progesterone and estrogen $(\mathrm{p}=0.08)$. Women who presented as being infertile had $23.5 \mathrm{ng} / \mathrm{L}$ higher serum levels of musk xylene than those who had already been pregnant once $(\mathrm{p}=0.045)$. However, given that nitro musks are lipophilic the lower levels of musk xylene in fertile women can possibly be explained by elimination of nitro musk through breast feeding. These findings are suggestive and may indicate that nitro musks could be disruptors of the hypothalamic-ovarian hormone pathway and further research is necessary to evaluate this relationship.

\section{Conclusion}

The use of animal models and laboratory studies is important for the risk assessment process. However, it can be difficult to extrapolate how these studies apply to typical everyday exposures of humans. The exposure concentrations of the nitro musks in the various animal models addressed above ranged from $1 \mu \mathrm{l} / \mathrm{L}$ to $5000 \mu \mathrm{l} / \mathrm{L}$. Considering nitro musks have been found in aquatic systems at lower concentrations and that humans have significantly more body mass than the animals being studied, the studies may not be applicable to human nitro-musk exposure. At the same time, many of these animal studies involved short duration exposures. Although human exposure is likely at lower doses, it also is likely to be longterm. The animal studies do not address this exposure scenario.

The body of literature supports the conclusion that not only are we being exposed to nitro musks, we are also bioaccumulating them and passing them on to our offspring through breast milk and perinatal exposures. While the animal studies do not address long-term low dose effects, they do indicate that a particular area of focus for health outcomes from nitro musk exposure should be tumor genesis and cancer. While animal studies were conflicting for potential developmental effects, this lack of agreement indicates that more research needs to be done in this field. Human endocrine effects have been seen for nitro musk exposures; this indicates that more studies need to be done in animals and humans at environmentally relevant exposure levels. In light of the evidence, the precautionary principle should be taken into account. This can be done through a reduction in the use and production of products containing nitro musks.

\section{Additional file}

Additional file 1: Summary of nitromusk toxicity studies performed

in animals and human cell lines.

\section{Abbreviations}

REACH: Registration, Evaluation, Authorization and Restriction of Chemicals; $\checkmark P \vee B$ : Very persistent, very bioaccumulative.

\section{Competing interests}

The authors declare that they have no competing interests. 


\section{Authors' contributions}

KMT did a systematic review of the literature and drafted the manuscript. MGW participated in the drafting and coordination of the paper and critically revised the manuscript. JPS conceived of the review study and critically revised the manuscript. All gave approval of the final manuscript.

\section{Acknowledgements}

The work was supported by the IMSD Academic Training grant (R25 GM055353 (K.T.)).

\section{Author details}

${ }^{1}$ Department of Environmental Health, Harvard School of Public Health, 677 Huntington Avenue, Boston, MA 02115, USA. ²Department of Epidemiology, Harvard School of Public Health, 677 Huntington Avenue, Boston, MA 02115, USA.

Received: 16 April 2013 Accepted: 24 February 2014

Published: 11 March 2014

\section{References}

1. Rimkus $\mathrm{GG}$, Wolf M: Nitro musk fragrances in biota from freshwater and marine environment. Chemosphere 1995, 30(4):641-651.

2. Ford RA, Domeyer B, Easterday O, Maier K, Middleton J: Criteria for development of a database for safety evaluation of fragrance ingredients. Regul Toxicol Pharmacol 2000, 31(2 Pt 1):166-181.

3. Spencer PS, Bischoff-Fenton MC, Moreno OM, Opdyke DL, Ford RA: Neurotoxic properties of musk ambrette. Toxicol Appl Pharmacol 1984, 75(3):571-575

4. Roosens L, Covaci A, Neels H: Concentrations of synthetic musk compounds in personal care and sanitation products and human exposure profiles through dermal application. Chemosphere 2007, 69(10):1540-1547.

5. Verbruggen ESD, Van lersel P, Schwarz-Schulz B, Olsson H, Paya Perez A: PBT Assessment of 5-Tert-Butyl-2,4,6-Trinitro-M-Xylene (Musk Xylene) Addendum to the Final Risk Assessment Report. In JRC Technical and Scientific Reports. Edited by Anklam E. Ispra (VARESE) - Italy: European Commission Joint Research Centre Institute for Health and Consumer Protection; 2008

6. Villa S, Assi L, Ippolito A, Bonfanti P, Finizio A: First evidences of the occurrence of polycyclic synthetic musk fragrances in surface water systems in Italy: spatial and temporal trends in the Molgora River (Lombardia Region, Northern Italy). Sci Total Environ 2012, 416:137-141.

7. Wang H, Zhang J, Gao F, Yang Y, Duan H, Wu Y, Berset JD, Shao B: Simultaneous analysis of synthetic musks and triclosan in human breast milk by gas chromatography tandem mass spectrometry. J Chromatogr $B$ Analyt Technol Biomed Life Sci 2011, 879(21):1861-1869.

8. Lu Y, Yuan T, Wang W, Kannan K: Concentrations and assessment of exposure to siloxanes and synthetic musks in personal care products from China. Environ Pollut 2011, 159(12):3522-3528.

9. Lu Y, Yuan T, Yun SH, Wang W, Kannan K: Occurrence of synthetic musks in indoor dust from China and implications for human exposure. Arch Environ Contam Toxicol 2011, 60(1):182-189.

10. Sofuoglu A, Kiymet N, Kavcar P, Sofuoglu SC: Polycyclic and nitro musks in indoor air: a primary school classroom and a women's sport center. Indoor Air 2010, 20(6):515-522.

11. Hawkins DR, Elsom LF, Kirkpatrick D, Ford RA, Api AM: Dermal absorption and disposition of musk ambrette, musk ketone and musk xylene in human subjects. Toxicol Lett 2002, 131(3):147-151.

12. Hutter HP, Wallner P, Moshammer H, Hartl W, Sattelberger R, Lorbeer G, Kundi M: Synthetic musks in blood of healthy young adults: relationship to cosmetics use. Sci Total Environ 2009, 407(17):4821-4825.

13. Lignell S, Darnerud PO, Aune M, Cnattingius S, Hajslova J, Setkova L, Glynn A: Temporal trends of synthetic musk compounds in mother's milk and associations with personal use of perfumed products. Environ Sci Technol 2008, 42(17):6743-6748

14. Eisenhardt S, Runnebaum B, Bauer K, Gerhard I: Nitromusk compounds in women with gynecological and endocrine dysfunction. Environ Res 2001 87(3):123-130.

15. Riedel J, Dekant W: Biotransformation and toxicokinetics of musk xylene in humans. Toxicol Appl Pharmacol 1999, 157(2):145-155.
16. Zhang $X, X u$ Q, Man S, Zeng $X, Y u$ Y, Pang $Y$, Sheng G, Fu J: Tissue concentrations, bioaccumulation, and biomagnification of synthetic musks in freshwater fish from Taihu Lake, China. Environ Sci Pollut Res Int 2013, 20(1):311-322.

17. Yamagishi T, Miyazaki T, Horii S, Akiyama K: Synthetic musk residues in biota and water from Tama River and Tokyo Bay (Japan). Arch Environ Contam Toxicol 1983, 12(1):83-89.

18. Kafferlein $\mathrm{H}$, Angerer J: Musk Xylene - is it still of relevance in Environmental Medicine [Abstract]. Umweltmed Forsch Prax 1999, 4(4):204-205.

19. Riedel J, Birner G, van Dorp C, Neumann HG, Dekant W: Haemoglobin binding of a musk xylene metabolite in man. Xenobiotica 1999, 29(6):573-582

20. Kokot-Helbling KS: Critical Kinetic Aspects of Lipophilic Compounds: I. Volatile Organic Compounds as Food Contaminants: II. Musk Xylene in Humans and Laboratory Animals. In PhD thesis. Swiss Federal Institute of Technology Zurich, Department of Natural Sciences; 1995

21. Tas JW, Balk F, Ford RA, van de Plassche EJ: Environmental risk assessment of musk ketone and musk xylene in The Netherlands in accordance with the EU-TGD. Chemosphere 1997, 35(12):2973-3002.

22. Rimkus G, Rimkus B, Wolf M: Nitro musks in human adipose tissue and breast milk. Chemosphere 1994, 28(2):421-432

23. Reiner JL, Wong CM, Arcaro KF, Kannan K: Synthetic musk fragrances in human milk from the United States. Environ Sci Technol 2007. 41(11):3815-3820.

24. Peck AM, Hornbuckle KC: Synthetic musk fragrances in Lake Michigan. Environ Sci Technol 2004, 38(2):367-372.

25. Hajkova K, Pulkrabova J, Hajslova J, Randak T, Zlabek V: Chub (Leuciscus cephalus) as a bioindicator of contamination of the Vltava River by synthetic musk fragrances. Arch Environ Contam Toxicol 2007, 53(3):390-396.

26. Peck AM, Hornbuckle KC: Aquatic processes and systems in perspective. J Environ Monit 2006, 8(9):874-879.

27. Herberer T, Gramer S, Stan H: Occurrence and distribution of organic contaminants in the aquatic system in the Berlin Part III: determination of synthetic musks in berlin surface water applying Solid-Phase Microextraction (SPME). Acta Hydrochimica et Hydrobiologica 1999, 27(3):150-156

28. Committee on the Assessment of Water Reuse as an Approach to Meeting Future Water Supply Needs: Water Reuse: potential for expanding the Nation's water supply through reuse of Municipal wastewater. In Washington, DC: The National Academies Press; 2012.

29. Reemtsma T, Weiss S, Mueller J, Petrovic M, Gonzalez S, Barcelo D, Ventura F, Knepper TP: Polar pollutants entry into the water cycle by municipal wastewater: a European perspective. Environ Sci Technol 2006, 40(17):5451-5458

30. Bogdal C, Schmid P, Zennegg M, Anselmetti FS, Scheringer M Hungerbuhler $\mathrm{K}$ : Blast from the past: melting glaciers as a relevant source for persistent organic pollutants. Environ Sci Technol 2009, 43(21):8173-8177.

31. Christian MS, Parker RM, Hoberman AM, Diener RM, Api AM: Developmental toxicity studies of four fragrances in rats. Toxicol Lett 1999, 111(1-2):169-174.

32. Carlsson G, Orn S, Andersson PL, Soderstrom H, Norrgren L: The impact of musk ketone on reproduction in zebrafish (Danio rerio). Mar Environ Res 2000, 50(1-5):237-241.

33. Chou YJ, Dietrich DR: Toxicity of nitromusks in early lifestages of South African clawed frog (Xenopus laevis) and zebrafish (Danio rerio). Toxicol Lett 1999, 111(1-2):17-25.

34. Gregoraszczuk EL, Ptak A, Skaare JU, Mularz K, Chmielowiec A, Wojtowicz A Ropstad E: Mechanisms of action of two different natural mixtures of persistent organic pollutants (POPs) in ovarian follicles. Xenobiotica 2009, 39(1):80-89.

35. Mullerova D, Kopecky J: White adipose tissue: storage and effector site for environmental pollutants. Physiol Res 2007, 56(4):375-381.

36. Chou YJ, Dietrich DR: Interactions of nitromusk parent compounds and their amino-metabolites with the estrogen receptors of rainbow trout (Oncorhynchus mykiss) and the South African clawed frog (Xenopus laevis). Toxicol Lett 1999, 111(1-2):27-36.

37. Bitsch N, Dudas C, Korner W, Failing K, Biselli S, Rimkus G, Brunn H: Estrogenic activity of musk fragrances detected by the E-screen assay using human mcf-7 cells. Arch Environ Contam Toxicol 2002, 43(3):257-264. 
38. Maekawa A, Matsushima Y, Onodera H, Shibutani M, Ogasawara H, Kodama Y, Kurokawa Y, Hayashi Y: Long-term toxicity/carcinogenicity of musk xylol in B6C3F1 mice. Food Chem Toxicol 1990, 28(8):581-586.

39. Kevekordes S, Zaulig A, Dunkelberg H: Genotoxicity of nitro musks in the micronucleus test with human lymphocytes in vitro and the human hepatoma cell line Hep G2. Toxicol Lett 1997, 91(1):13-17.

40. Api AM, Gudi R: An in vivo mouse micronucleus assay on musk ketone. Mutat Res 2000, 464(2):263-267.

41. Kevekordes S, Grahl K, Zaulig A, Dunkelberg H: Optimization of a Sensitive Method for the Determination of Nitro Musk Fragrances in Waters by Solid-Phase Microextractions and Gas Chromatography with Micro Electron Capture Detection using Factorial Experimental Design. Environ Sci Pollut Res Int 1996, 3(4):189-192.

42. Mersch-Sundermann $V$, Emig M, Reinhardt A: Nitro musks are cogenotoxicants by inducing toxifying enzymes in the rat. Mutat Res 1996, 356(2):237-245.

43. Mersch-Sundermann $V$, Schneider $H$, Freywald $C$, Jenter $C$, Parzefall $W$ Knasmuller S: Musk ketone enhances benzo(a)pyrene induced mutagenicity in human derived Hep G2 cells. Mutat Res 2001, 495(1-2):89-96.

44. Iwata N, Minegishi K, Suzuki K, Ohno Y, Kawanishi T, Takahashi A: Musk xylene is a novel specific inducer of cytochrome P-450IA2. Biochem Biophys Res Commun 1992, 184(1):149-153.

45. Stuard SB, Caudill D, Lehman-McKeeman LD: Characterization of the effects of musk ketone on mouse hepatic cytochrome P450 enzymes. Fundam Appl Toxicol 1997, 40(2):264-271.

46. Schnell S, Martin-Skilton R, Fernandes D, Porte C: The interference of nitro- and polycyclic musks with endogenous and xenobiotic metabolizing enzymes in carp: an in vitro study. Environ Sci Technol 2009, 43(24):9458-9464.

47. Luckenbach T, Epel D: Nitromusk and polycyclic musk compounds as long-term inhibitors of cellular xenobiotic defense systems mediated by multidrug transporters. Environ Health Perspect 2005, 113(1):17-24.

doi:10.1186/1476-069X-13-14

Cite this article as: Taylor et al:: Human exposure to nitro musks and the evaluation of their potential toxicity: an overview. Environmental Health 2014 13:14.

\section{Submit your next manuscript to BioMed Central and take full advantage of:}

- Convenient online submission

- Thorough peer review

- No space constraints or color figure charges

- Immediate publication on acceptance

- Inclusion in PubMed, CAS, Scopus and Google Scholar

- Research which is freely available for redistribution 